\title{
Low Density Lipoprotein (LDL)-Antioxidant Flavonoids from Roots of Sophora flavescens
}

\author{
Tae-Sook Jeong, ${ }^{b}$ Young Bae Ryu, ${ }^{a}$ Hoi Young Kim, ${ }^{a}$ Marcus John Curtis-Long, ${ }^{d}$ So Jin An, ${ }^{b}$ \\ Jin Hwan LeE, ${ }^{a}$ Woo Song LeE, ${ }^{*, c}$ and Ki Hun PARK ${ }^{*, a}$ \\ ${ }^{a}$ Division of Applied Life Science (BK21 Program), EB-NCRC, Institute of Agriculture \& Life Science, Gyeongsang \\ National University; Jinju 660-701, Republic of Korea: ${ }^{b}$ National Research Laboratory of Lipid Metabolism \& \\ Atherosclerosis, Korea Research Institute of Bioscience and Biotechnology; Daejeon 305-333, Republic of Korea: \\ ${ }^{c}$ Bioindustry Research Center, KRIBB; Jeongeup 580-185, Republic of Korea: and ${ }^{d} 12$ New Road, Nafferton, Driffield, \\ East Yorkshire, YO25 4JP, U.K.
}

Received May 27, 2008; accepted July 23, 2008; published online August 8, 2008

Oxidation of low density lipoprotein (LDL) is strongly implicated as a key process in the onset of atherosclerosis. In this study, nine alkylated $\left(\mathrm{C}_{10}-\mathrm{C}_{5}\right)$ flavonoids from Sophora flavescens were examined for their inhibitory effects on copper-induced LDL oxidation. Of the flavonoids tested, sophoraflavanone G (1), kurarinone (2), kurarinol (3), norkurarinol (4), and kuraridin (9) inhibited the generation of thiobarbituric acid reactive substances (TBARS) with $\mathrm{IC}_{50}$ s of $7.9,14.5,22.0,26.9$, and $17.5 \mu_{\mathrm{M}}$, respectively. The most potent inhibitor, compound 1, also demonstrated significant activities in complementary in vitro investigations, such as lag time $\left(130 \mathrm{~min}\right.$ at $5 \mu_{\mathrm{M}}$ ), relative electrophoretic mobility (REM) of ox-LDL (80\% inhibition at $\left.20 \mu_{\mathrm{M}}\right)$, and fragmentation of apoB-100 (inhibition of $71 \%$ at $20 \mu \mathrm{M}$ ). Analysis of the structures of these compounds reveals that a resorcinol moiety in the B-ring is strongly correlated with protection of LDL-oxidation.

Key words Sophora flavescens; low density lipoprotein oxidation; sophoraflavanone G; kurarinone; resorcinol

Oxidative stress caused by reactive oxygen species (ROS) threatens the integrity of various biomolecules including proteins, lipids and DNA. These degradation pathways have been implicated in a number of degenerative processes, including ageing, Alzheimer's disease and atherosclerosis. In the case of the latter, oxidative stress is believed to be involved through the formation of oxidized low density lipoprotein (ox-LDL). When LDL is oxidized by ROS, it is modified in several ways and the build-up of oxidized LDL within arterial walls promotes several steps in atherosclerosis, ${ }^{1,2)}$ including endothelial cell damage. ${ }^{3)}$ Moreover monocyte-derived macrophages recognize and absorb ox-LDL through scavenger receptors, which unlike Brown/Goldstein LDL receptors are unregulated. These results in massive accumulation of lipids and the proliferation of foam cells. ${ }^{4)}$ For these reasons, LDL-antioxidants are of great interest, with particular attention focused on therapeutic strategies to prevent atherosclerosis.

In order to find out the crucial component of naturally-derived remedies believed to serve for the prevention or treatment of atherosclerosis, many polyphenols with LDL-antioxidant activity have been isolated from various fruits, vegetables, and plants. ${ }^{5)}$ Recently, we also reported that lignan, neolignan, and xanthone isolated from Myristica fragrans and Cudrania tricuspidata inhibit LDL oxidation. ${ }^{6,7)}$ In our continued screening of cholesterol-lowering, antiatherosclorotic agents, we found that the methanolic extracts of roots of $S$. flavescens exhibited significant LDL-antioxidant activity.

Sophora flavescens, which is known as the Chinese drug 'kushen' has been used as a stamachic, antipyretic, analgesic, and insecticide. ${ }^{8)}$ Biological investigations have mainly focused on its antibacterial, cytotoxic, tyrosinase inhibitory, and glycosidase inhibitory properties. ${ }^{9-12)}$ Although the antioxidant benefits of flavonoids from $S$. flavescens have been reported in a few cases, ${ }^{13,14)}$ there is no report as to whether the compounds inhibit LDL oxidation and thus their utility toward atherosclerosis treatment is currently not known.

In this study, we isolated 9 compounds from the roots of $S$. flavescens and their structures were identified using spectroscopic methods. The isolated compounds were evaluated for their inhibitory activity against copper-induced LDL oxidation by four methods: thiobarbituric acid reactive substances (TBARS) assay, ${ }^{15)}$ measurement of the formation of conjugated dienes, ${ }^{16}$ relative electrophoretic mobility (REM), ${ }^{17)}$ and fragmentation of apoB-100. ${ }^{18)}$

\section{MATERIALS AND METHODS}

General All purifications were monitored by TLC using commercially available glass-backed plates. Column chromatography was carried out using 230-400 mesh silica gel. Melting points were measured on a Thomas Scientific capillary melting point apparatus (Electrothermal 9300, U.K.) and are uncorrected. IR spectra were recorded on a Bruker IFS66 (Bruker, Karlsruhe, Germany) IR Fourier transform spectrophotometer $(\mathrm{KBr}) .{ }^{1} \mathrm{H}$ - and ${ }^{13} \mathrm{C}-\mathrm{NMR}$ as well as $2 \mathrm{D}-\mathrm{NMR}$ data were obtained on a Bruker AM $500\left({ }^{1} \mathrm{H}-\mathrm{NMR}\right.$ at $500 \mathrm{MHz},{ }^{13} \mathrm{C}-\mathrm{NMR}$ at $125 \mathrm{MHz}$ ) spectrometer (Bruker, Karlsruhe, Germany) in either $\mathrm{CDCl}_{3}$, acetone- $d_{6}$, and $\mathrm{CD}_{3} \mathrm{OD}$. Optical rotation values were measured by a PerkinElmer 343 polarimeter and $[\alpha]_{\mathrm{D}}$-values are given in units of $10^{-1} \mathrm{deg} \mathrm{cm}^{2} \mathrm{~g}^{-1}$. Chromatographic separation was achieved using an Agilent 1100 liquid chromatograph (Agilent Technologies, Palo Alto, CA, U.S.A.) equipped with a quaternary HPLC pump, a degasser, and autosampler and UV detector (PDA). All the reagent grade chemicals were purchased from Sigma (Sigma Chemical Co., St. Louis, MO, U.S.A.).

Plant Material Sophora flavescens was collected in Hamyang (Korea) and identified by Prof. Myong Gi Chung. A voucher specimen (Park, K. H. 112) of this raw material is deposited at Herbarium of Gyeongsang National University 
(GNU).

Extraction and Isolation Dried roots of Sophora flavescens $(2.4 \mathrm{~kg})$ were repeatedly extracted with methanol at room temperature. The combined extracts were filtered and concentrated to yield a dark brown residue, which was partitioned between water and chloroform. The organic layer was concentrated to give a brown residue $(53 \mathrm{~g})$. The chloroform extract was column chromatographed, eluted with a mixture of hexane/EtOAc, of increasing polarity $(20: 1 \rightarrow$ $1: 10)$. Seven pooled fractions (Fr. I-Fr. VII) were obtained after combining fractions with similar TLC profiles from this initial purification step. Repeated column chromatography of these pooled fractions on silica gel furnished $230 \mathrm{mg}$ of compound $\mathbf{1}, 270 \mathrm{mg}$ of compound $\mathbf{2}, 60 \mathrm{mg}$ of compound $\mathbf{3}$, $30 \mathrm{mg}$ of compound $4,410 \mathrm{mg}$ of compound $\mathbf{5}, 170 \mathrm{mg}$ of compound $\mathbf{6}, 210 \mathrm{mg}$ of compound $7,40 \mathrm{mg}$ of compound $\mathbf{8}$, and $97 \mathrm{mg}$ of compound 9. ${ }^{12)}$

Isolation of LDL Blood was obtained from healthy volunteers who had given their consent according to the 'Guidelines of Blood Donation Program for Research' of the Korean Red Cross Blood Center. EDTA was used as an anticoagulant $(1.5 \mathrm{mg} / \mathrm{ml}$ of blood). After low speed centrifugation of the whole blood to obtain plasma and to prevent lipoprotein modification, $0.1 \%$ EDTA, $0.05 \% \mathrm{NaN}_{3}$, and $0.015 \%$ PMSF (phenylmethanesulfonyl fluoride) were added. LDL $(1.019-1.063 \mathrm{~g} / \mathrm{ml})$ was isolated from the plasma by sequential density ultracentrifugation at $4{ }^{\circ} \mathrm{C}$ in a Beckman TL ultracentrifuse (Beckman Instruments, Mountain View, CA, U.S.A.) as described previously. ${ }^{19)}$ After isolation, LDL was dialyzed overnight against three changes of phosphate buffer ( $\mathrm{pH} 7.4$ ), containing $150 \mathrm{~mm} \mathrm{NaCl}$, in the dark at $4{ }^{\circ} \mathrm{C}$ to remove EDTA. The LDL in phosphate-buffered saline (PBS) was stored at $4^{\circ} \mathrm{C}$ and used within 4 weeks.

$\mathrm{Cu}^{2+}$-Induced LDL Oxidation and TBARS Assay The TBARS assay of Buege and Aust ${ }^{15)}$ was used with some modifications. Briefly, a solution of LDL $(250 \mu \mathrm{l}, 120 \mu \mathrm{g}$ of protein) in PBS $(10 \mathrm{~mm}, \mathrm{pH} 7.4,0.15 \mathrm{M} \mathrm{NaCl})$ was supplemented with $10 \mathrm{~mm} \mathrm{CuSO}_{4}$. The oxidation was performed in a screw-capped $5 \mathrm{ml}$ glass vial at $37^{\circ} \mathrm{C}$ in the presence or absence of test compounds. After $4 \mathrm{~h}$ incubation, the reaction was terminated by addition of $1 \mathrm{ml}$ of $20 \%$ trichloroacetic acid. Following precipitation, $1 \mathrm{ml}$ of $0.67 \%$ thiobarbituric acid in $0.05 \mathrm{~N} \mathrm{NaOH}$ was added and vortexed, and the final mixture was heated for $5 \mathrm{~min}$ at $95^{\circ} \mathrm{C}$, then cooled on ice, and centrifuged for $2 \mathrm{~min}$ at $1000 \times \mathbf{g}$. The optical density of the produced malondialdehyde (MDA) was measured at $532 \mathrm{~nm}$.

Conjugated Diene Formation The formation of conjugated diene was measured by monitoring the absorbance at $234 \mathrm{~nm}$ using the modification method. ${ }^{16)}$ Briefly, LDL $(120 \mathrm{mg} / \mathrm{ml})$, in PBS (pH 7.4) was incubated with $5 \mu \mathrm{M}$ aqueous $\mathrm{CuSO}_{4}$ in the presence or absence of test compounds $(1-9)$, at $37^{\circ} \mathrm{C}$ for $4 \mathrm{~h}$; thereafter, the absorbance at $234 \mathrm{~nm}$ was measured every $10 \mathrm{~min}$. The lag time was measured as the intercept between the baseline and the tangent of the absorbance curve during the propagation phase.

Relative Electrophoretic Mobility (REM) The electrophoretic mobility of native or oxidized LDL was detected by agarose gel electrophoresis (Ciba Corning Diagnostics, Palo Alto, CA, U.S.A.) using the method of Reid and Mitchinson. ${ }^{17)}$ The LDL $(120 \mu \mathrm{g} / \mathrm{ml})$ in PBS (pH 7.4) was oxidized with $5 \mathrm{~mm} \mathrm{CuSO}_{4}$ for $12 \mathrm{~h}$ at $37^{\circ} \mathrm{C}$ in the presence or absence of test compounds (1-9). Thereafter, the mixture was electrophoresed $(85 \mathrm{~V})$ on an agarose gel $(0.7 \%$ agarose $)$ in a buffer containing $40 \mathrm{~mm}$ Tris, $40 \mathrm{~mm}$ glacial acetic acid, and $1 \mathrm{~mm}$ EDTA for $1 \mathrm{~h}$. After electrophoresis, lipoprotein bands were stained with coomassie blue; REM was defined as the ratio of the migrating distance of oxidized LDL to that of the control.

Electrophoresis of Fragmented ApoB-100 The degree of fragmentation of apoB-100 was evaluated using electrophoresis as described previously. ${ }^{18)}$ After the oxidation in the presence or absence of antioxidants, samples were denatured with 3\% SDS, 10\% glycerol, and 5\% 2-mercaptoethanol at $95{ }^{\circ} \mathrm{C}$ for $10 \mathrm{~min}$. SDS-polyacrylamide gel electrophoresis (SDS PAGE, 3-5\% gradient) was performed to detect the apoB-100 fragmentation. The gel was subjected to electrophoresis at $48 \mathrm{~V}$ for $150 \mathrm{~min}$. After the electrophoresis, the gel was dried and stained with coomassie brilliant blue R250 and subjected to densitometric scanning by a Bio $\operatorname{Rad}^{\circledR}$ Model GS-800 with Bio Rad ${ }^{\circledR}$ Quantity One-4.4.0 software.

HPLC Apparatus and Chromatographic Conditions The pulverized roots of $S$. flavescens $(1.0 \mathrm{~g})$ were extracted with $40 \mathrm{ml} \mathrm{MeOH}$ using sonication at $60^{\circ} \mathrm{C}$. The extracts used for HPLC analysis were passed through $0.45-\mu \mathrm{m}$ filters (Millipore, MSI, Westboro, MA, U.S.A.). HPLC separation of isolated polyphenols was performed on a Agilent 1100 series instrument equipped with $\mathrm{PDA}$ using a $\mathrm{C}_{18}$ column [LichiroCART 125-4 HPLC-Cartridge (Lichrphore 100 RP$18 \mathrm{e}, \varphi 5 \mu \mathrm{m}$, Merck)]. The mobile phase for HPLC consisted of solvent $\mathrm{A}, 0.1 \%$ acetic acid in water, and solvent $\mathrm{B}, 0.1 \%$ acetic acid in acetonitrile. The solvent gradient was as follows (relative to solvent A): $0 \mathrm{~min}, 30 \% \mathrm{~B} ; 25 \mathrm{~min}, 60 \% \mathrm{~B}$; $35 \mathrm{~min}, 100 \% \mathrm{~B}$. The flow rate was $1.0 \mathrm{ml} / \mathrm{min}$ and the injection was volume $10 \mu \mathrm{l}$. The eluent was detected at $286 \mathrm{~nm}$ and all HPLC analyses were performed at $30^{\circ} \mathrm{C}$.

Data Analysis All values are expressed as mean standard deviation (S.D.) of two independent experiments performed in duplicate. Statistical analysis was performed using a $t$-test. A value of $p<0.05$ was considered statistically significant.

\section{RESULTS AND DISCUSSION}

The methanol (95\%) extract of Sophora flavescens at $40 \mu \mathrm{g} / \mathrm{ml}$ caused $80 \%$ inhibition of LDL-oxidation (TBARS assay). Subsequent bioactivity-guided fractionation of the $\mathrm{MeOH}$ extracts led to the isolation of nine compounds: seven flavanones (1-7), one flavanol (8), and one chalcone (9). The structures of compounds $\mathbf{1 - 9}$ were identified as sophoraflavanone G (1), kurarinone (2), kurarinol (3), norkurarinol (4), kushenol A (5), (2S)-2' -methoxykurarinone (6), isoxanthohumol (7), 3,7,4'-trihydroxy-5-methoxy-8-prenylflavanone (8), and kuraridin (9) as shown in Table 1 on the basis of spectroscopic analyses. The physical and spectroscopic data of $\mathbf{1}-\mathbf{9}$ agree with the previously reported data. ${ }^{12,20-24)}$ Herein, we report some important physical data including ${ }^{13} \mathrm{C}-\mathrm{NMR}$ spectroscopic data.

Sophoraflavanone $\mathrm{G}$ (1): Amorphous white powder; $\mathrm{mp}$ $178-180^{\circ} \mathrm{C}$; EI-MS $\mathrm{m} / \mathrm{z}$ (relative intensity): $424\left(\mathrm{M}^{+}\right.$, 11.5\%), 301 (79.7), 283 (100), 219 (14), 165 (79.1); $[\alpha]$ 
$-71.4^{\circ}(c=2.0, \mathrm{MeOH})$; UV $\lambda_{\max } \mathrm{nm}: 292,332(\mathrm{MeOH})$; ${ }^{13} \mathrm{C}-\mathrm{NMR}\left(125 \mathrm{MHz}, \mathrm{CD}_{3} \mathrm{OD}\right) \delta: 76.2(\mathrm{~d}, \mathrm{C}-2), 43.7$ (t, C-3), 199.4 (s, C-4), 163.6 (s, C-5), 96.7 (d, C-6), 166.9 (s, C-7), 109.1 (s, C-8), 103.7 (s, C-4a), 163.0 (s, C-8a), 118.8 (s, C1'), 157.1 (s, C-2'), 108.1 (d, C-3'), 159.9 (s, C-4'), 103.8 (d, C-5'), 129.1 (d, C-6'), 28.4 (t, C-1"), 48.7 (d, C-2"), 32.8 (t, C-3"), 125.2 (d, C-4"), 132.4 (s, C-5"), 18.3 (q, C-6"), 26.3 (q, C-7"), 150.1 (s, C-8"), 19.6 (q, C-9"), $111.6\left(\mathrm{t}, \mathrm{C}-10^{\prime \prime}\right) .^{20,21)}$

Kurarinone (2): Colorless powder; mp $117-119^{\circ} \mathrm{C}$; EIMS $m / z$ (relative intensity): $438\left(\mathrm{M}^{+}, 1.9 \%\right), 436$ (2.6), 418 (16.7), 299 (100), 297 (29), 179 (27.7), 153 (33.6); [ $\alpha]$ $-35.2^{\circ}(c=2.0, \mathrm{MeOH}) ; \mathrm{UV} \lambda_{\max } \mathrm{nm}: 286,371(\mathrm{MeOH})$; ${ }^{13} \mathrm{C}-\mathrm{NMR}\left(125 \mathrm{MHz}, \mathrm{CD}_{3} \mathrm{OD}\right) \delta: 75.9$ (d, C-2), $46.0(\mathrm{t}, \mathrm{C}-3)$, 194.3 (s, C-4), 162.3 (s, C-5), 93.7 (d, C-6), 165.3 (s, C-7), 110.0 (s, C-8), 106.2 (s, C-4a), 165.1 (s, C-8a), 118.9 (s, C1'), 157.7 (s, C-2'), 108.1 (d, C-3'), 159.9 (s, C-4'), 103.8 (d, C-5'), 128.9 (d, C-6'), $28.6\left(\mathrm{t}, \mathrm{C}-1^{\prime \prime}\right), 48.6$ (d, C-2"), $32.8(\mathrm{t}$, C-3"), 125.2 (d, C-4"), 132.4 (s, C-5"), 18.2 (q, C-6"), 26.3 (q, C-7"), 150.2 (s, C-8"), 19.6 (q, C-9"), 111.6 (t, C-10"), 56.3 $\left(\mathrm{C} 5-\mathrm{OCH}_{3}\right){ }^{22)}$

Kurarinol (3): Amorphous yellow powder; mp 166$169^{\circ} \mathrm{C} ;[\alpha]-40^{\circ}(c=1.0, \mathrm{MeOH})$; UV $\lambda_{\max }$ nm: 287,367 $(\mathrm{MeOH}) ;{ }^{13} \mathrm{C}-\mathrm{NMR}\left(125 \mathrm{MHz}, \mathrm{CD}_{3} \mathrm{OD}\right) \delta: 75.9$ (d, C-2), 46.0 (t, C-3), 194.4 (s, C-4), 106.2 (s, C-4a), 162.3 (s, C-5), 93.8 (d, C-6), 165.3 (s, C-7), 109.9 (s, C-8), 165.1 (s, C-8a), 118.8 (s, C-1'), 157.1 (s, C-2'), 128.9 (d, C-3'), 159.9 (s, C$\left.4^{\prime}\right), 103.8$ (d, C-5'), 108.1 (d, C-6'), 29.1 (t, C-1"), 49.3 (d, C$\left.2^{\prime \prime}\right), 28.5\left(\mathrm{t}, \mathrm{C}-3^{\prime \prime}\right), 43.2\left(\mathrm{t}, \mathrm{C}-4^{\prime \prime}\right), 71.9\left(\mathrm{~s}, \mathrm{C}-5^{\prime \prime}\right), 29.3$ (q, C$\left.6^{\prime \prime}\right), 29.6$ (q, C-7"), 150.0 (s, C-8"), 15.9 (q, C-9"), 112.0 (t, $\left.\mathrm{C}-10^{\prime \prime}\right), 56.4\left(\mathrm{C} 5-\mathrm{OCH}_{3}\right){ }^{12)}$

Norkurarinol (4): Colorless powder; mp $102-104^{\circ} \mathrm{C}$; EIMS $m / z$ (relative intensity): $442\left(\mathrm{M}^{+}, 1.9 \%\right), 301$ (76.8), 283 (100), 165 (67.9); $[\alpha]-75.8^{\circ}(c=0.5, \mathrm{MeOH}) ;{ }^{13} \mathrm{C}-\mathrm{NMR}$ $\left(125 \mathrm{MHz}\right.$, acetone- $\left.d_{6}\right) \delta: 75.8(\mathrm{~d}, \mathrm{C}-2), 43.0(\mathrm{t}, \mathrm{C}-3), 198.6$ (s, C-4), 163.4 (s, C-5), 96.7 (d, C-6), 165.8 (s, C-7), 108.3 (s, C-8), 118.3 (s, C-4a), 162.5 (s, C-8a), 108.4 (s, C-1'), 156.7 (s, C-2'), 104.0 (d, C-3'), 159.8 (s, C-4'), 103.7 (d, C$\left.5^{\prime}\right), 129.1\left(\mathrm{~d}, \mathrm{C}-6^{\prime}\right), 43.0$ (t, C-1" $), 48.6$ (d, C-2"), 28.6 (t, C$\left.3^{\prime \prime}\right), 28.1$ (t, C-4"), 70.9 (s, C-5"), 30.1 (q, C-6"), 29.9 (q, C$\left.7^{\prime \prime}\right), 149.6$ (s, C-8"), 19.1 (q, C-9"), $111.8\left(\mathrm{t}, \mathrm{C}-10^{\prime \prime}\right){ }^{23)}$

Kushenol A (5): Amorphous white powder; mp 175$178^{\circ} \mathrm{C}$; EI-MS $\mathrm{m} / z$ (relative intensity): $408\left(\mathrm{M}^{+}, 9.9 \%\right), 285$ (100), 267 (68.9), 165 (63.7); $[\alpha]-106.5^{\circ}(c=2.0, \mathrm{MeOH})$; UV $\lambda_{\max } \mathrm{nm}: 224,291(\mathrm{MeOH}) ;{ }^{13} \mathrm{C}-\mathrm{NMR} \quad(125 \mathrm{MHz}$, CD 3 OD) $\delta: 76.3$ (d, C-2), 43.6 (t, C-3), 199.0 (s, C-4), 163.7 (s, C-5), 96.9 (d, C-6), 167.0 (s, C-7), 109.1 (s, C-8), 103.7 (s, C-4a), 163.8 (s, C-8a), 127.6 (s, C-1'), 155.6 (s, C-2'), 116.7 (d, C-3'), 130.6 (d, C-4'), 121.0 (d, C-5'), 127.6 (d, C$\left.6^{\prime}\right), 28.4$ (t, C-1"), 48.7 (d, C-2"), 32.7 (t, C-3"), 125.1 (d, C$\left.4^{\prime \prime}\right), 132.5$ (s, C-5"), 18.2 (q, C-6"), 26.2 (q, C-7"), 150.1 (s, $\left.\mathrm{C}-8^{\prime \prime}\right), 19.7$ (q, C-9") $111.6\left(\mathrm{t}, \mathrm{C}-10^{\prime \prime}\right) .^{12)}$

(2S)-2'-Methoxykurarinone (6): Pale yellow powder; $\mathrm{mp}$ $112-115^{\circ} \mathrm{C}$; EI-MS $\mathrm{m} / \mathrm{z}$ (relative intensity): $452\left(\mathrm{M}^{+}\right.$, 6.3\%), 329 (32.5), 179 (100); $[\alpha]-35.4^{\circ}(c=2.0, \mathrm{MeOH})$; UV $\lambda_{\max } \mathrm{nm}: 277,288(\mathrm{MeOH}) ;{ }^{13} \mathrm{C}-\mathrm{NMR} \quad(125 \mathrm{MHz}$, CD $\left.{ }_{3} \mathrm{OD}\right) \delta: 75.9$ (d, C-2), 46.0 (t, C-3), 194.3 (s, C-4), 106.2 (s, C-4a), 165.3 (s, C-5), 93.7 (d, C-6), 165.3 (s, C-7), 110.0 (s, C-8), 165.1 (s, C-8a), 118.9 (s, C-1'), 157.1 (s, C-2'), 108.1 (d, C-3'), 159.9 (s, C-4'), 103.8 (d, C-5'), 128.9 (d, C$\left.6^{\prime}\right), 28.6\left(\mathrm{t}, \mathrm{C}-{ }^{\prime \prime}\right), 48.6\left(\mathrm{~d}, \mathrm{C}-2^{\prime \prime}\right), 32.8\left(\mathrm{t}, \mathrm{C}-3^{\prime \prime}\right), 125.2$ (d, C$\left.4^{\prime \prime}\right), 132.4$ (s, C-5"), 18.2 (q, C-6"), 26.3 (q, C-7"), 150.2 (s,
C-8"), 19.6 (q, C-9"), $111.6\left(\mathrm{t}, \mathrm{C}-10^{\prime \prime}\right), 56.3\left(\mathrm{OCH}_{3}\right), 56.2$ $\left(\mathrm{OCH}_{3}\right){ }^{12,22)}$

Isoxanthohumol (7): Amorphous white powder; mp 196$208^{\circ} \mathrm{C}$; EI-MS $m / z$ (relative intensity): $354\left(\mathrm{M}^{+}, 100 \%\right), 311$ (49.9), 299 (19.5), 217 (47.2), 191 (43.8), 179 (91.5); [ $\alpha]$ $-19.6^{\circ}(c=2.0, \mathrm{MeOH}) ; \mathrm{UV} \lambda_{\max } \mathrm{nm}: 286,368(\mathrm{MeOH})$; ${ }^{13} \mathrm{C}-\mathrm{NMR}\left(125 \mathrm{MHz}, \mathrm{CD}_{3} \mathrm{OD}\right) \delta: 80.4(\mathrm{~d}, \mathrm{C}-2), 46.6(\mathrm{t}, \mathrm{C}-3)$, 193.3 (s, C-4), 106.3 (s, C-4a), 162.2 (s, C-5), 93.9 (d, C-6), 164.7 (s, C-7), 110.4 (s, C-8), 164.2 (s, C-8a), 132.1 (s, C$\left.1^{\prime}\right), 129.1$ (s, C-2'), 116.7 (d, C-3'), 159.2 (s, C-4'), 116.5 (d, C-5'), 129.3 (d, C-6'), 23.1 (t, C-1"), 124.3 (d, C-2"), 132.0 $\left.\left(\mathrm{s}, \mathrm{C}-3^{\prime \prime}\right), 18.3\left(\mathrm{q}, \mathrm{C}-4^{\prime \prime}\right), 26.4\left(\mathrm{q}, \mathrm{C}-5^{\prime \prime}\right), 56.4\left(\mathrm{C} 5-\mathrm{OCH}_{3}\right) .{ }^{12}\right)$

3,7,4'-Trihydroxy-5-methoxy-8-prenylflavanone (8): Colorless powder; mp $194-198^{\circ} \mathrm{C}$; EI-MS $\mathrm{m} / z$ (relative intensity): $370\left(\mathrm{M}^{+}, 3.2 \%\right), 354$ (65.9), 311 (44), 219 (39.5), 179 $(100) ;[\alpha]-4.2^{\circ}(c=0.5, \mathrm{MeOH}) ;{ }^{13} \mathrm{C}-\mathrm{NMR} \quad(125 \mathrm{MHz}$, $\left.\mathrm{CD}_{3} \mathrm{OD}\right) \delta: 74.0(\mathrm{~d}, \mathrm{C}-2), 84.2(\mathrm{~d}, \mathrm{C}-3), 191.7$ (s, C-4), 161.5 (s, C-5), 94.2 (d, C-6), 163.5 (s, C-7), 109.6 (s, C-8), 103.8 (s, C-4a), 163.1 (s, C-8a), 131.7 (s, C-1'), 130.5 (d, C-2'), 116.2 (d, C-3'), 159.0 (s, C-4'), 116.2 (d, C-5'), 130.5 (d, C$\left.6^{\prime}\right), 22.7$ (t, C-1"), 123.9 (d, C-2"), 130.1 (s, C-3"), 18.2 (q, C$\left.4^{\prime \prime}\right), 26.2\left(\mathrm{q}, \mathrm{C}-5^{\prime \prime}\right), 56.4\left(\mathrm{C} 5-\mathrm{OCH}_{3}\right){ }^{24)}$

Kuraridin (9): Amorphous yellow powder; mp 114 $116^{\circ} \mathrm{C}$; EI-MS $\mathrm{m} / \mathrm{z}$ (relative intensity): $438\left(\mathrm{M}^{+}, 2.7 \%\right), 299$ (26.3), 297 (13.3), 179 (24.9), 153 (100); $[\alpha]-1.0^{\circ}(c=0.5$, $\mathrm{MeOH}) ;{ }^{13} \mathrm{C}-\mathrm{NMR}\left(125 \mathrm{MHz}, \mathrm{CD}_{3} \mathrm{OD}\right) \delta: 140.2(\mathrm{~d}, \mathrm{C}-2)$, 125.9 (d, C-3), 195.2 (s, C-4), 162.9 (s, C-5), 92.0 (d, C-6), 164.4 (s, C-7), 109.3 (s, C-8), 107.0 (s, C-4a), 109.3 (s, C8a), 160.7 (s, C-1' ), 116.7 (s, C-2'), 109.4 (d, C-3'), 162.8 (s, C-4'), 104.1 (d, C-5'), 132.0 (d, C-6'), 28.6 (t, C-1"), 48.2 (d, C-2"), 32.8 (t, C-3"), 125.5 (d, C-4"), 132.2 (s, C-5"), 18.3 (q, C-6"), 26.3 (q, C-7"), 150.3 (s, C-8"), 111.5 (t, C-9"), 19.5 (q, $\left.\mathrm{C}-10^{\prime \prime}\right), 56.5\left(\mathrm{C} 5-\mathrm{OCH}_{3}\right){ }^{12)}$

Initially, compounds $\mathbf{1}-\mathbf{9}$ were measured in order to compare their LDL-antioxidant activities using the TBARS assay, which is a good general method to measure the amount of oxidized lipid present in a medium. The results are summarized in Table 1. Among of them, compound 1 bearing 5,7dihydroxy and $2^{\prime}, 4^{\prime}$-dihydroxy groups showed the highest LDL-antioxidant activity $\left(\mathrm{IC}_{50}=7.9 \mu \mathrm{M}\right)$. On the other hand compound $\mathbf{6}$, the direct analogue of $\mathbf{1}$ with hydroxyl functions at positions 5 and $2^{\prime}$ capped with methyl groups, was significantly less active. Compound $\mathbf{5}$ which possess the same functionality in the A-ring as compound $\mathbf{1}$, but has a lone hydroxyl group in the B-ring, displayed very low activity. Interestingly, C5-O-methylated derivative 2, exhibited a two folds lower activity than compound 1. Compounds 7 and 8 which possess the same structure as compound $\mathbf{2}$ in the Aring, but contain only a $5^{\prime}$-hydroxy group in the B-ring were practically inactive against LDL-oxidation. Perhaps most poignantly, inactive flavonoids $(\mathbf{5}-\mathbf{8})$ differed from the most effective inhibitors screened, flavanones $\mathbf{1}$ and $\mathbf{2}$, only in the fact that they lacked a resorcinol moiety within the B ring.

In terms of structure-activity relationship, these results clearly implicate the resorcinol moiety within the B-ring as the key functional element: it was present in all active flavonoids (1-4) and absent from the inactive one. To investigate this we also assayed chalcone $\mathbf{9}$. This compound, despite being structurally very different from the flavones studied above, nonetheless contains a resorcinol-type appendage and thus should show activity. Indeed, 9 was found to have an 
Table 1. Inhibitory Effects of Isolated Compounds $\mathbf{1}-\mathbf{9}$ on $\mathrm{Cu}^{2+}$-Mediated LDL Oxidation by Measurement of TBARS Assay<smiles>[R]c1cc(O)c([2H])c2c1C(=O)C([2H])C(c1ccc(Br)cc1[2H])O2</smiles>

\begin{tabular}{|c|c|c|c|c|c|c|}
\hline Compound & $\mathrm{R}^{1}$ & $\mathrm{R}^{2}$ & $\mathrm{R}^{3}$ & $\mathrm{R}^{4}$ & $\mathrm{R}^{5}$ & $\mathrm{IC}_{50}(\mu \mathrm{M})$ values $\left.^{a}\right)$ \\
\hline 1 & & $\mathrm{OH}$ & $\mathrm{H}$ & $\mathrm{OH}$ & $\mathrm{OH}$ & 7.9 \\
\hline 2 & & $\mathrm{OMe}$ & $\mathrm{H}$ & $\mathrm{OH}$ & $\mathrm{OH}$ & 14.5 \\
\hline 3 & & $\mathrm{OMe}$ & $\mathrm{H}$ & $\mathrm{OH}$ & $\mathrm{OH}$ & 22.0 \\
\hline 4 & & $\mathrm{OH}$ & $\mathrm{H}$ & $\mathrm{OH}$ & $\mathrm{OH}$ & 26.9 \\
\hline 5 & & $\mathrm{OH}$ & $\mathrm{H}$ & $\mathrm{OH}$ & $\mathrm{H}$ & $46.9 \pm 1.6^{b)}$ \\
\hline 6 & & $\mathrm{OMe}$ & $\mathrm{H}$ & $\mathrm{OMe}$ & $\mathrm{OH}$ & $16.2 \pm 0.3^{b)}$ \\
\hline 7 & & $\mathrm{OMe}$ & $\mathrm{H}$ & $\mathrm{H}$ & $\mathrm{OH}$ & $6.3 \pm 0.9^{b)}$ \\
\hline 8 & & $\mathrm{OMe}$ & $\mathrm{OH}$ & $\mathrm{H}$ & $\mathrm{OH}$ & $14.2 \pm 3.8^{b)}$ \\
\hline 9 & & - & - & - & - & 17.5 \\
\hline
\end{tabular}
a) A $\mathrm{A}$.
$40 \mu \mathrm{M}$.

$\mathrm{IC}_{50}$ of $17.5 \mu \mathrm{M}$. The preeminence of the resorcinol moiety can be accounted for at least in part by the fact that it is highly electron-rich and thus may serve as a sacrificial oxidant. On the other hand, the 5-hydroxy group within the Aring is not mandatory for high activity. For instance, compounds $\mathbf{1}$ and $\mathbf{2}$ only differ by a factor of $\mathbf{2}$ despite the latter being C5-O-methylated. The alkyl group on the A-ring $\left(\mathrm{R}^{1}\right)$ was also shown to confer most potency when it was more hydrophobic as shown by compound 1 vs. compound 4 . On the basis of these results, compounds $\mathbf{1}$ and $\mathbf{2}$ were selected for further studies as they displayed the most potent LDL-antioxidant activity.

The formation of conjugated dienes constituents the first step of LDL oxidation. Monitoring diene formation ( $234 \mathrm{~nm}$ ) as a function of time can elucidate the relative resistance of LDL to oxidation. As shown in Fig. 1, LDL $(120 \mu \mathrm{g} / \mathrm{ml})$ incubated with $5 \mu \mathrm{M}$ of $\mathrm{CuSO}_{4}$ had a lag time of $58 \mathrm{~min}$ (control). At an inhibitor concentration of $5 \mu \mathrm{M}$, the lag time was extended to $130 \mathrm{~min}$ in the presence of $\mathbf{1}$ and $115 \mathrm{~min}$ in the presence of $\mathbf{2}$. These data correlate with the activities found

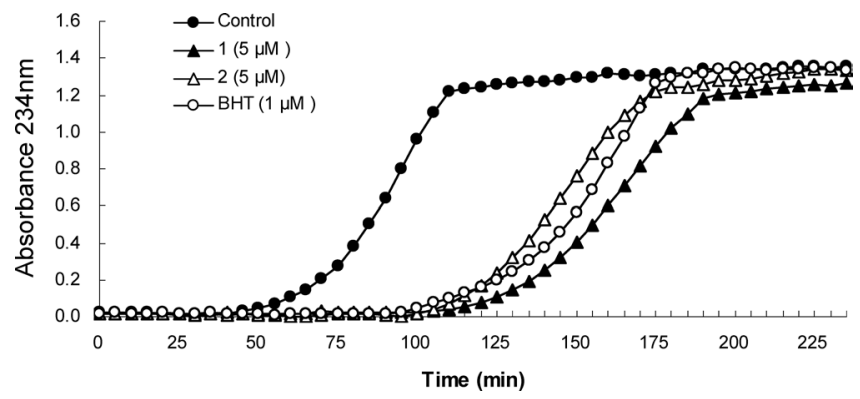

Fig. 1. Effects of Compounds $\mathbf{1}$ and $\mathbf{2}$ on the Generation of Conjugated Diene

Conjugated diene formation was measured by determining the absorbance at $234 \mathrm{~nm}$ every $10 \mathrm{~min}$ for $4 \mathrm{~h}$. Butylated hydroxytoluene (BHT) was used as a reference antioxidant. Values shown are a representative of 2 experiments.

in the TBARS assay.

We progressed to examine the effect of $\mathbf{1}$ and $\mathbf{2}$ on $\mathrm{Cu}^{2+}$ mediated LDL oxidation using a REM assay. As shown in Fig. 2, incubation of the enzyme with $\mathrm{CuSO}_{4}$ for $12 \mathrm{~h}$ re- 


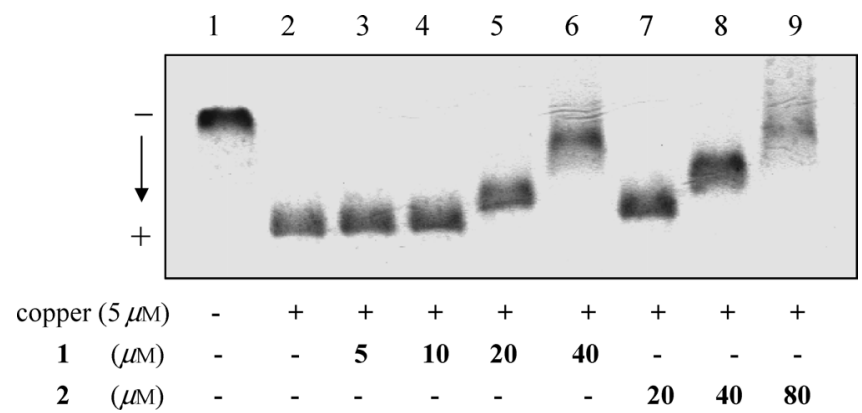

Fig. 2. Effect of Compounds $\mathbf{1}$ and $\mathbf{2}$ on Relative Electrophoretic Mobility of LDL

Lane 1, native LDL (absence of $\left.\mathrm{CuSO}_{4}\right)$; lane 2, ox-LDL; lane 3, $1(5 \mu \mathrm{M})$; lane 4, 1 $(10 \mu \mathrm{M}) ;$ lane 5, $1(20 \mu \mathrm{M}) ;$ lane 6, $1(40 \mu \mathrm{M})$; lane 7, $2(20 \mu \mathrm{M}) ;$ lane 8, $2(40 \mu \mathrm{M})$; lane $9,2(80 \mu \mathrm{M})$.
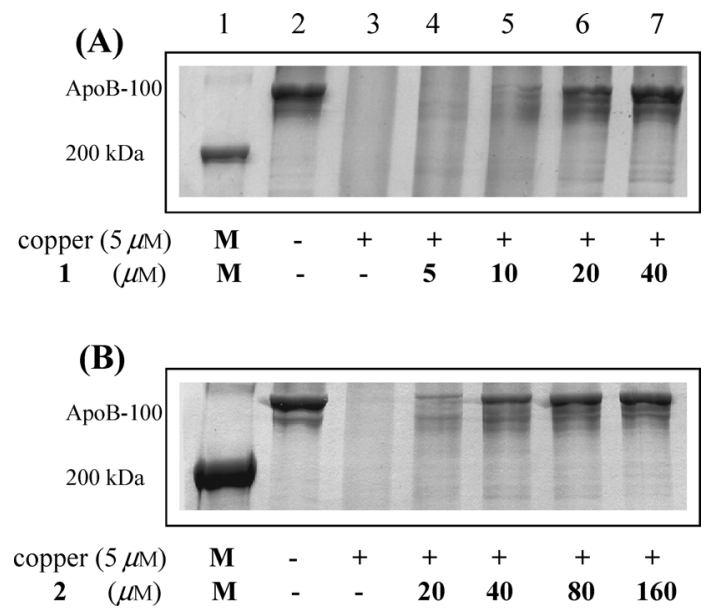

Fig. 3. Antioxidant Effects of Compounds $\mathbf{1}$ and $\mathbf{2}$ on the ApoB-100 Fragmentation

(A) Lane 1, molecular weight marker; lane 2, native LDL (absence of $\mathrm{CuSO}_{4}$ ); lane 3, ox-LDL; lane 4, $1(5 \mu \mathrm{M})$; lane 5, $1(10 \mu \mathrm{M})$; lane 6, $1(20 \mu \mathrm{M})$; lane 7, $1(40 \mu \mathrm{M}) ; \mathrm{M}$ (marker); (B) lane 1, molecular weight marker; lane 2, native LDL (absence of $\mathrm{CuSO}_{4}$ ); lane 3, ox-LDL; lane 4, $2(20 \mu \mathrm{M})$; lane 5, $2(40 \mu \mathrm{M})$; lane 6, $2(80 \mu \mathrm{M})$; lane 7, 2 $(160 \mu \mathrm{M}) ; \mathrm{M}$ (marker)

sulted in significant oxidation of the enzyme. As characterized by a significant change in the protein's REM. We were able to attenuate this effect considerably (up to $80 \%$ ) by the addition of compound $\mathbf{1}$. This was shown to be dose-dependent across an 8-fold concentration range. In the case of compound 2, results were similar. However, in line with its lower potency, a larger concentration was required to engender a similar effect.

The inhibition of the oxidative process of compounds 1 and $\mathbf{2}$, and probucol were evaluated also by the fragmentation of lipoprotein apoB-100 through analysis via sodium dodecylsulfate polyacrylamide gel (4\%) electrophoresis (SDSPAGE). When LDL $(120 \mu \mathrm{g} / \mathrm{ml}$ in $10 \mathrm{~mm}$ PBS, pH 7.4) was incubated in the absence of $\mathrm{CuSO}_{4}$, a band corresponding to the native protein was clearly visible. However, this band completely disappeared when LDL $(120 \mu \mathrm{g} / \mathrm{ml}$ in PBS) was incubated with $5 \mu \mathrm{M}$ of $\mathrm{CuSO}_{4}$. We were able to retard this degradation process by adding inhibitor 1. Again this was shown to be dose dependent, with $>20 \mu \mathrm{M}$ eliciting a significant effect. Compound 2 also showed similar but less pronounced activity. Table 2 shows the densitometric analysis of this data: in the presence of 20 and $40 \mu \mathrm{M}$ of 1 , the percent-
Table 2. Oxidative Modification on SDS-PAGE of ApoB-100

\begin{tabular}{cc}
\hline \hline Compound $(\mu \mathrm{M})$ & Protection $(\%)^{a)}$ \\
\hline Native LDL & 100 \\
Ox-LDL & 0 \\
$\mathbf{1}(20)$ & 71 \\
$\mathbf{1}(40)$ & 109 \\
$\mathbf{2}(40)$ & 56 \\
$\mathbf{2}(80)$ & 80 \\
$\mathbf{2}(160)$ & 89
\end{tabular}

a) Densitometric analysis of the apoB-100 expressed as relative protection $\%$ on the basis of native $\mathrm{LDL}$

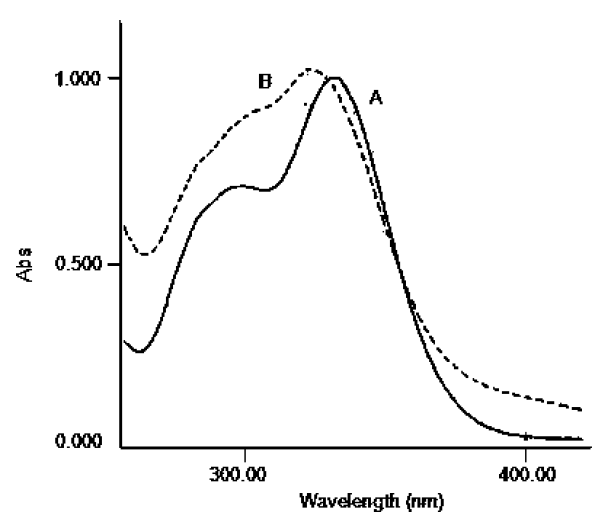

Fig. 4. UV-vis Spectrum of Compound $1(50 \mu \mathrm{M})$, (A) without and (B) with $\mathrm{CuSO}_{4}(100 \mu \mathrm{M})$

age of remaining apoB-100 relative to intact apoB-100 was $71 \%$ and $109 \%$, respectively. Thus, compound 1 has potent activity in the protection of apoB-100 fragmentation against copper-mediated oxidation of LDL.

LDL-oxidation was caused by a catalytic amount of copper(II) ions in solution. We accordingly speculated that the antioxidant effect could be attributed to the resorcinol moiety within the inhibitors chelating the copper. Consistent with this hypothesis, when compound $1(50 \mu \mathrm{M})$ and copper(II) $(100 \mu \mathrm{M})$ were mixed together, a $20 \mathrm{~nm}$ blue shift $(338 \rightarrow$ $320 \mathrm{~nm}$ ) was observed at UV-vis spectrum of the inhibitor (Fig. 4). This indicates that the copper ion interacts with the inhibitor.

The quantity of active component contained within the plant source in one further important factor with which to evaluate neutraceuticals. Thus, the relative proportion of each of the isolated compounds was confirmed by HPLC analysis $\left(\mathrm{C}_{18}\right.$-column $)$ (Fig. 5). The chromatographic profile implies that the most active LDL-antioxidants $(\mathbf{1}, \mathbf{2})$ detailed within this study are the predominant secondary metabolites of Sophora flavescens.

In summary, the bioassay-guided fractionation from methanol extract of $S$. flavescens yielded nine compounds, and among them, five $[(\mathbf{1}-\mathbf{4}$ (flavonoids), 9 (chalcone) showed LDL-antioxidant activities in TBARS assay with $\mathrm{IC}_{50} \mathrm{~s}$ of $7.9,14.5,22.0,26.9$, and $17.5 \mu \mathrm{M}$, respectively. From this data we conclude that a resorcinol moiety in the B-ring is pivotal for LDL-antioxidant activity. The most active species, compounds 1 and 2, also exhibited potent dose-dependent activities in complementary in vitro investigation, such as lag time in diene formation, REM of ox-LDL, and fragmentation of apoB-100 on copper-mediated LDL oxidation. With re- 


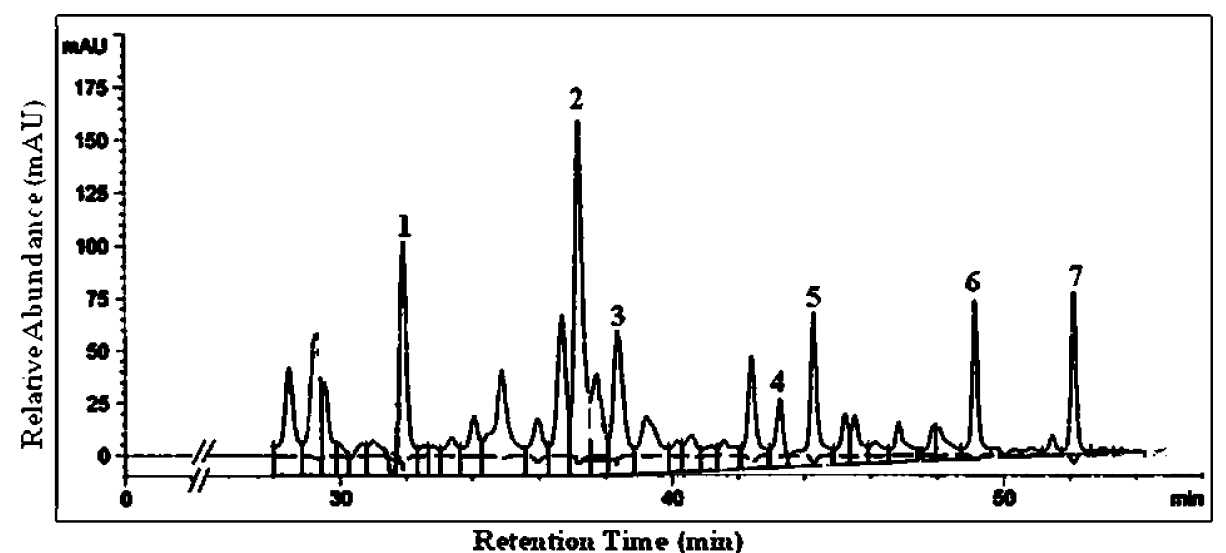

Fig. 5. Representative HPLC Chromatogram of Polyphenols in S. flavescens

1: isoxanthohumol (7) (retention time: $31.89 \mathrm{~min}), 2$ : kurarinone (2) (37.17 min), 3: kurarinol (3) (38.36 min), 4: (2S)-2'-methoxykurarinone (6) (43.24 min), 5: sophoraflavanone G (1) (44.26 min), 6: kuraridin (9) (49.12 min), 7: kushenol A (5) (52.10 min).

gard to structure-activity relationship, it has been demonstrated that resorcinol moiety of B-ring is a critical functionality for LDL-antioxidant.

Acknowledgements This work was financially supported by a grant (20080401-034-063-008-03) form BioGreen 21 Project Program, Rural Development Administration, Republic of Korea and KRIBB research initiative program, Republic of Korea. Y. B. Ryu was supported by a grant from the BK21 Program.

\section{REFERENCES}

1) Steinberg D., Parthasrathy S., Carew T. E., Khoo J. C., Witztum J. L., N. Engl. J. Med., 320, 915-923 (1989).

2) Steinberg D., Nat. Med., 8, $1211-1217$ (2002).

3) Liao L., Statzyk R. M., Granger D. N., Arterioscler. Thromb. Vasc. Biol., 17, 437-444 (1997).

4) Dejager S., Mietus-Synder M., Pitas R. E., Arterioscler. Thromb., 13, $371-378$ (1993).

5) Rice-Evans C. A., Miller N. J. Paganga G., Free Radic. Biol. Med., 20, 933-956 (1996).

6) Kwon H. S., Kim M.-J., Jeong H. J., Yang M. S., Park K. H., Jeong T.S., Lee W. S., Bioorg. Med. Chem. Lett., 18, 194-198 (2008).

7) Park K. H., Park Y. D., Han J. M., Im K.-R., Lee B. W., Jeong I. Y., Jeong T.-S., Lee W. S., Bioorg. Med. Chem. Lett., 16, 5580-5583 (2006).

8) Murakoshi I., Ito M., Haginiwa J., Ohmiya S., Otomasu H., Hirano R.
T., Phytochemisty, 23, 887-891 (1984).

9) Ko W. G., Kang T. H., Kim N. Y., Lee S. J., Kim Y. C., Ko G. I., Ryu S. Y., Lee B. H., Toxicology, 14, 429-433 (2000).

10) Kuroyanagi M., Arakawa T., Hirayama Y., Hayashi T., J. Nat. Prod., 62, 1595-1599 (1999).

11) Kim S. J., Son K. H., Chang H. W., Kang S. S., Kim H. P., Biol. Pharm. Bull., 26, 1348-1350 (2003).

12) Kim J. H., Ryu Y. B., Kang N. S., Lee B. W., Heo J. S., Jeong I.-Y., Park K. H., Biol. Pharm. Bull., 29, 302-305 (2006).

13) Piao X.-L., Piao X. S., Kim S. W., Park J. H., Kim H. Y., Cai S.-Q., Biol. Pharm. Bull., 29, 1911-1915 (2006).

14) Jung H. A., Jeong D.-M., Chung H. Y., Lim H. A., Kim J. Y., Yoon N. Y., Choi J. S., Biol. Pharm. Bull., 31, 908-915 (2008).

15) Buege J. A., Aust S. D., Methods Enzymol., 52, 302-310 (1978)

16) Esterbauer H., Stiegal G., Puhl H., Rotheneder M., Free Radic. Res. Commun., 6, 67-75 (1989).

17) Reid V. C., Mitchinson M. J., Atherosclerosis, 98, 17-24 (1993).

18) Noguchi N., Niki E., Methods Enzymol., 233, 490-494 (1994).

19) Havel R. J., Eder H. A., Bragdon J. H., J. Clin. Invest., 34, 1345-1353 (1955).

20) Iinuma M., Tanaka T., Mizuno M., Shirataki Y., Yokoe I., Komatsu M., Lang F. A., Phytochemisty, 29, 2667-2669 (1990).

21) Shirataki Y., Yokoe I., Noguchi M., Tomimori T., Komatsu M., Chem. Pharm. Bull., 36, 2220-2225 (1988).

22) Kang T.-H., Jeong S.-J., Ko W.-G., Kim N.-Y., Lee B.-H., Inagaki M., Miyamoto T., Higuchi R., Kim Y.-C., J. Nat. Prod., 63, 680-681 (2000).

23) Ryu S. Y., Kim S.-K., No Z., Ahn J. W., Planta Med., 62, 361-363 (1996).

24) Jakupovic J., Paredes L., Bohlmann F., Watson L., Phytochemisty, 27, 3273 -3275 (1988). 